\title{
Knowledge, Attitude and Practice on Diabetic Wound Care Management among Healthcare Professionals and Impact from A Short Course Training in Sabah, Borneo
}

\author{
Sağlık Uzmanları Arasında Diyabetik Yara Bakımı Yönetimi Hakkındaki \\ Bilgi, Tutum ve Uygulamalar ile Sabah, Borneo'daki Kısa Süreli Bir \\ Eğitimin Etkisi
}

\author{
Melvin Ebin BONDI $\odot$, Syed Sharizman Syed Abdul RAHIM $\odot$, Richard AVOi $\odot$, Firdaus HAYATi $\odot$, \\ Fatimah AHMEDY $\odot$, Azizan OMAR $\odot$, Mohammad Saffree JEFFREE $\odot$, Awang Setia MUSLEH $\odot$
}

Ethics Committee Approval: This study was approved by the Universiti Malaysia Sabah, Jawatankuasa Etika Penyelidikan Perubatan, Clinical Studies Ethics Committee, 8 March 2020, JKEtika 1/20(14). Conflict of interest: The authors declare that they have no conflict of interest.

Funding: None.

Informed Consent: Informed consent was taken from the patients enrolled in this study.

\begin{abstract}
Objective: Healthcare professionals with an advanced level of knowledge and skills on diabetic wound care management are needed to effectively manage complex wounds. This study aimed to determine the effects of an educational intervention to enhance the management of wound care among healthcare professionals.

Method: This study was part of a quasi-experimental pre-post research design where 82 healthcare professionals were recruited and assigned to intervention and control groups. The participants in the intervention group attended two days of educational intervention training on diabetic wound care management, while there was no intervention in the control group. A questionnaire on knowledge, attitude, and practice was applied before and one-month post-intervention to both groups.

Results: Pre-test resulted in a low level of knowledge $72.1 \%$ and $74.4 \%$, negative level of attitude $67.4 \%$ and $66.7 \%$, and a moderate level of practice $79.1 \%$ and $76.9 \%$ in both intervention and control groups respectively. Post-test resulted in increasing levels of knowledge (76.7\%), positive attitude (100\%), and practice $(76.7 \%)$ in the intervention group. At the same time, there was no significant change in the control group. Repeated Measure ANOVA for within-subject and betweensubject effects resulted in a statistically significant p-value of 0.001 for knowledge, attitude, and practice after the educational intervention.

Conclusion: Health professionals have only a moderate level of knowledge on diabetic wound care management. It is important to improve this level by specific trainings and by using a good training module.
\end{abstract}

Keywords: Attitude, educational intervention, knowledge, practice, diabetic wound care management

öz

Amaç: Karmaşık yapıdaki yaraları etkili bir şekilde yönetmek için diyabetik yara bakımı yönetimi konusunda üst düzeyde bilgi ve beceriye sahip sağlık uzmanlarına ihtiyaç vardır. Bu çalıșmada, sağlık çalışanları arasında yara bakımı yönetimini geliștirmeye yönelik bir eğitimsel müdahalenin etkilerinin belirlenmesi amaçlamaktadır.

Yöntem: Bu çalışma, 82 sağlık uzmanının müdahale ve kontrol gruplarına atandığı ön-son değerlendirmelerin olduğu yarı deneysel desende bir arastırmanın parçasıdır. Müdahale grubundaki katılımcılar, diyabetik yara bakımı yönetimi konusunda iki günlük eğitimsel bir müdahaleye katılırken, kontrol grubunda herhangi bir müdahale olmamıştır. Müdahaleden önce ve bir ay sonra her iki gruba bilgi, tutum ve uygulama üzerine bir anket uygulanmıştır.

Bulgular: On-test hem müdahale hem de kontrol grubunda sirasiyla $\% 72,1$ ve $\% 74,4$ olumsuz tutum; \%67,4 ve \%66,7 orta seviyede uygulama düzeyi; \%79,1 ve \%76,9 ile düşük bilgi düzeyleriyle sonuçlanmıştır. Son-test ise müdahale grubunda bilgi düzeyi $(\% 76,7)$, olumlu tutum düzeyi $(\% 100)$ ve yüksek düzeyde uygulama (\%76,7) için artıslarla sonuçlanmıstır. Aynı zamanda, kontrol grubunda önemli bir değişiklik olmamıştır. Gruplar içi ve gruplar arası etki için uygulanan Tekrarlanan Ölçümlerde ANOVA, eğitimsel müdahaleden sonra bilgi, tutum ve uygulama için istatistiksel olarak anlamlı bir p-değeri $(0,001)$ ile sonuçlanmıștır.

Sonuç: Sağlık çalışanları diyabetik yara bakımı yönetimi konusunda yalnızca orta düzeyde bilgiye sahiptir. Bu seviyeyi konuya özel tasarlanmış eğitimlerle ve iyi bir eğitim modülü kullanarak iyileştirmek önemlidir.

Anahtar kelimeler: Tutum, eğitimsel müdahale, bilgi, uygulama, diyabetik yara bakımı yönetimi

(c) Copyright Istanbul Medeniyet University Faculty of Medicine. This journal is published by Logos Medical Publishing.

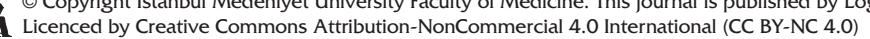

Received: 8 May 2020

Accepted: 15 July 2020

Online First: 30 September 2020

Corresponding Author: S.S.S.A. Rahim

ORCID: 0000-0002-9090-2563

Universiti Malaysia Sabah,

Department of Community and

Family Medicine, Kota Kinabalu,

Sabah, Malaysia

syedsharizman@gmail.com

M.E. Bondi

ORCID: 0000-0002-5383-854X

Putatan Health Clinic, Department of

Primary Health Care, Putatan,

Sabah, Malaysia

R. Avoi

ORCID: 0000-0002-1957-0965

A. Omar

ORCID: 0000-0002-3369-4075

M.S. Jeffree

ORCID: 0000-0002-0373-4451

A.S. Musleh

ORCID: 0000-0002-6214-6860

University Malaysia Sabah, Department of Community and Family Medicine, Kota Kinabalu,

Sabah, Malaysia

F. Hayati

ORCID: 0000-0002-3757-9744

University Malaysia Sabah, Department of Surgery, Kota Kinabalu, Sabah, Malaysia

F. Ahmedy

ORCID: 0000-0002-5811-4188

University Malaysia Sabah, Department of Medical Education, Kota Kinabalu,

Sabah, Malaysia

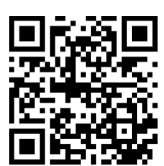


M.E. Bondi et al. Knowledge, Attitude and Practice on Diabetic Wound Care Management among Healthcare Professionals and Impact from A Short Course Training in Sabah, Borneo

\section{INTRODUCTION}

Wound care management is crucial for wound healing with minimal or no complications. The concept of cleaning the wound and bandages existed in 2100 BC where wound cleansing was used in homes with available products such as beer and hot water for wound washing, mixtures of herbs, honey, and ointments as a primary layer and bandaging as an outer layer ${ }^{1}$. Revolution of wound dressing has evolved over the years, especially after the World War II, where first aid and surgical products were highly demanded. The practice of modern dressing was not commonly used then ${ }^{2}$.

Managing a diabetic wound requires multiple modalities of treatment such as medication, nutrition, and wound debridement aside from proper dressing technique alone ${ }^{3}$. Awareness of how vital wound care being done in the healthcare now becomes more clear where healthcare professionals, especially doctors and assistant medical officers with knowledge in complex wound care are in great demand ${ }^{4}$. As more and more complicated the wounds are, it is paramount to have equipped professionals equally competent and qualified to face these challenges heads ${ }^{5}{ }^{5}$. Wound infection and non-healing wounds represent a silent epidemic that affects a significant fraction of the world population especially on the life quality of the affected patients and poses major and gathering threat to the public health and economy. In the United Kingdom, around 200.000 patients have a chronic wound due to infection. The cost of caring patients with a chronic and infected wound is conservatively estimated at 2.3 billion to 3.1 billion per year ${ }^{6}$.

Educational intervention on diabetic wound care management has been seen as effective to improve knowledge, attitude, and practice among healthcare professionals. Many theories postulated that specific trainings could develop critical thinking and improve performances in medical students and healthcare professionals ${ }^{7}$. In 2014 , the Ministry of Health $(\mathrm{MOH})$ in Malaysia published the first edition of Wound Care Manual to be implemented in all hospitals in Malaysia. In January 2018, a circular was released by the $\mathrm{MOH}$ to erect a wound care unit in public health as a new key performance indicator (KPI). The establishment of the wound care unit in the public health serves as a continuity of care to patients discharged from the tertiary hospitals and addresses common types of wound including diabetic foot ulcers, pressure ulcers, burns, venous ulcers, arterial ulcers, and non-healing ulcers ${ }^{8}$.

In Malaysia, there is still limited information and a few studies available on wound care, particularly in public health, and there is no similar study conducted in Sabah, Malaysia and Borneo before. Wound care management is the vital responsibility of all healthcare professionals who involved in patient care where they are continuously challenged to provide a good quality patient care despite the lack of resources and poor level of knowledge, attitude, and practice on wound care management ${ }^{8}$. The patient was also economically affected due to unsatisfactory progress of wound healing despite frequent clinic visits. Some implications of poor management of wound care are the development of infection and delay in wound healing ${ }^{6}$ which requires frequent dressing visits of more than three months. The patient's quality of life are affected by all means such as they need to travel to the clinic for dressing, consuming fuel, and spending time including the waiting time to get the treatment.

This study aimed to determine the level of knowledge, attitude, and practice and the effects of the educational intervention (training) to enhance the management of wound care among healthcare professionals.

\section{MATERIALS and METHODS}

This is a quasi-experimental study with pre- and 
post-test design to assess the effects of the educational intervention on the level of knowledge, attitude, and post-implementation practice. The educational intervention module was developed by adapting the existing guidelines from the $\mathrm{MOH}$ to suit the setting and key performance indicators in public health. The intervention group was assigned to the Putatan Health Clinic and the control group to the Penampang Health Clinic. Both groups were assessed as for their knowledge, attitude, and practice before and one month after the educational training.

The development of the educational intervention training module was initiated in 2019, adapting the guidelines from the Ministry of Health, Malaysia and only focused on managing wounds in the primary healthcare setting. The module was designed and developed specifically on addressing common wound problems in the public health setting.

Bias was controlled by using a single-blind method where the participants were not informed that there were pre- and post-test in regard to avoiding contamination of the study. There was no other guideline used besides the module itself.

The inclusion criteria were the healthcare professionals working at Penampang Area Health Office clinically dealing with patients and wounds at the outpatient department. Herein, the term healthcare professionals referred to doctors, assistant medical officers, and staff nurses at Penampang Area Health Office. The participant must be a permanent staff, having roles and responsibilities in relation to the direct patient care. Participants must also have been working at that particular unit for a minimum of six months.

There were 82 participants recruited to participate in this study. There were 43 healthcare professionals in the intervention group and 39 healthcare professionals in the control group. The study was conducted on $10^{\text {th }}$ and $11^{\text {th }}$ February 2020 February.
The first material is a set of items in the questionnaire to determine the level of knowledge, attitude, and practice of healthcare professionals. The questionnaire was self-developed, had been validated and firstly used for the pilot study (Cronbach's Alpha $=0.87$ ). The questionnaire consisted of four parts: demographic characteristics, knowledge, attitude, and practice on wound care management ${ }^{9}$. Each questionnaire had 15 items where the level of knowledge was tested using true or false options, the level of attitude was tested using a 4-point Likert scale (Strongly Disagree, Disagree, Agree, and Strongly Agree), and the level of practice was tested using a 3-point rating scale (Always, Sometimes, and Never).

The educational intervention module was developed, and adapted from the Wound Care Guidelines by the Ministry of Health, Malaysia ${ }^{10}$. The educational intervention module consisted of three main sections: Basic wound principle, concept of wound care management, and principle aspect of wound care management. The educational training course held for two days which included lectures, demonstrations, and hands-on training as a platform for conducting the training.

This study has been registered to NMRR (NMRR19-3661-52018) and has obtained the Malaysian Research Ethics Committee approval (KKM/NIHSEC/P20-32 (12). This study has also received the UMS Ethics approval (UMS/FPSK6.9/100-6/195). All participants have been briefed and signed informed consent before taking part in the study. There was no risk for the participants and no conflict of interest involved in the study.

In this study, for statistical analysis, descriptive statistics was used to look at distribution of respondents demographic characteristics and baseline level of knowledge, attitude and practice in both groups. Other than that, Repeated Measures ANOVA was then used to measure the difference of the educational intervention to improve the 
level of knowledge and attitude and practice variables in both intervention and control groups.

\section{RESULTS}

The demographic background of the participants is shown in Table 1. Most of the participants were aged between 31 to 40 years, females outnumbered by $69.8 \%$ in the intervention group and $71.8 \%$ in the control group. Distribution of the participants by profession was as follows: doctors (33\%), assistant medical officers (24\%), and nurses $(43 \%)$. Most of the participants in both groups possessed diploma and degree as educational background. Nearly all of the participants have been working for 5-20 years.

\section{Knowledge}

Pre-test results demonstrated that $72.1 \%$ of the participants in the intervention group, and 74.4\% in the control group had a low level of knowledge. The $27.9 \%$ and $25.6 \%$ of the participants in the intervention and control groups had a moderate level of knowledge, respectively. None of the participants had a high level of knowledge in both groups during the pre-test. According to post-test results, $76.7 \%$ of the participants had a high level of knowledge. In comparison, there were no significant changes in the control group, where $61.5 \%$ of the participants had a low level of knowledge. These findings postulate that educational intervention does improve the level of knowledge on wound care management (Table 2).

\section{Attitude}

According to pre-test results in a majority of the participants in both groups had a negative attitude towards the management of wound care. The $67.4 \%$ and $66.7 \%$ of the participants in both intervention and control groups demonstrated a negative attitude during the pre-test, respectively. However, according to post-test results, a change of attitude level in the intervention group was revealed where $100 \%$ of the participants had a positive level of attitude, while only $38.5 \%$ of the participants in the control group had a positive level of attitude. These results suggest that changes in the attitude of healthcare professionals occur when an educational intervention towards the management of wound care is implemented (Table 2).

\section{Practice}

During the pre-test, the baseline level of practice for the participants in both groups were moderate, with $79.1 \%$ in the intervention group and $76.9 \%$ in the control group. Post-test resulted in a

Table 1. The demographic background of the participants.

\begin{tabular}{llll}
\hline & & Intervention Group (n=43) & Control Group (n=39) \\
\hline Age & $20-30$ years & $18.6 \%$ & $25.6 \%$ \\
& $31-40$ years & $51.2 \%$ & $61.5 \%$ \\
Gender & $41-50$ years & $30.2 \%$ & $12.8 \%$ \\
& Male & $30.2 \%$ & $28.2 \%$ \\
Profession & Female & $69.8 \%$ & $71.8 \%$ \\
& Doctor & $34.9 \%$ & $30.8 \%$ \\
Education level & Asst. Medical Officer & $23.3 \%$ & $25.6 \%$ \\
& Nurse & $41.9 \%$ & $43.6 \%$ \\
& Diploma & $34.9 \%$ & $38.5 \%$ \\
Lest Basic & $18.6 \%$ & $20.5 \%$ \\
& Degree & $37.2 \%$ & $35.9 \%$ \\
& Masters/PhD & $9.3 \%$ & $5.1 \%$ \\
& $<5$ years & $2.3 \%$ & $10.3 \%$ \\
& $5-10$ years & $53.5 \%$ & $46.2 \%$ \\
\end{tabular}


Table 2. Baseline level of knowledge, attitude, and practice in both groups.

\begin{tabular}{|c|c|c|c|c|}
\hline Test & Variables & Baseline level & Intervention Group $(n=43)$ & Control Group $(n=39)$ \\
\hline Pre-Test & Knowledge & $\begin{array}{l}\text { Low } \\
\text { Moderate } \\
\text { High }\end{array}$ & $\begin{array}{l}72.1 \%(n=31) \\
27.9 \%(n=12) \\
0 \%\end{array}$ & $\begin{array}{l}74.4 \%(n=29) \\
25.6 \%(n=10) \\
0 \%\end{array}$ \\
\hline & Attitude & $\begin{array}{l}\text { Negative } \\
\text { Positive }\end{array}$ & $\begin{array}{l}67.4 \%(n=29) \\
32.6 \%(14)\end{array}$ & $\begin{array}{l}66.7 \%(n=26) \\
33.3 \%(n=13)\end{array}$ \\
\hline & Practice & $\begin{array}{l}\text { Low } \\
\text { Moderate } \\
\text { High }\end{array}$ & $\begin{array}{l}20.9 \%(n=9) \\
79.1 \%(n=34) \\
0 \%\end{array}$ & $\begin{array}{l}23.1(n=9) \\
76.9 \%(n=30) \\
0 \%\end{array}$ \\
\hline Post-Test & Knowledge & $\begin{array}{l}\text { Low } \\
\text { Moderate } \\
\text { High }\end{array}$ & $\begin{array}{l}0 \% \\
2.4 \%(n=1) \\
97.7 \%(n=42)\end{array}$ & $\begin{array}{l}61.5 \%(n=24) \\
38.5 \%(n=15) \\
0 \%\end{array}$ \\
\hline & Attitude & $\begin{array}{l}\text { Negative } \\
\text { Positive }\end{array}$ & $\begin{array}{l}0 \% \\
100 \%(n=43)\end{array}$ & $\begin{array}{l}61.5 \%(n=24) \\
38.5 \%(n=15)\end{array}$ \\
\hline & Practice & $\begin{array}{l}\text { Low } \\
\text { Moderate } \\
\text { High }\end{array}$ & $\begin{array}{l}0 \% \\
23.3 \%(n=10) \\
76.7 \%(n=33)\end{array}$ & $\begin{array}{l}23.1 \%(n=9) \\
76.9 \%(n=30) \\
0 \%\end{array}$ \\
\hline
\end{tabular}

Table 3. Repeated Measures ANOVA (Within- and Between-subjects effect).

\begin{tabular}{|c|c|c|c|c|c|c|c|c|c|}
\hline \multirow[b]{2}{*}{ Variable } & \multirow[b]{2}{*}{ Group } & \multicolumn{4}{|c|}{ Within-subjects Effect } & \multicolumn{4}{|c|}{ Between-subjects Effect } \\
\hline & & df & df (error) & $\mathbf{F}$ & p-value & df & df (error) & $\mathbf{F}$ & p-value \\
\hline Knowledge & $\begin{array}{l}\text { Intervention Group } \\
\text { Control Group }\end{array}$ & 1 & 80 & 876.25 & 0.001 & 1 & 80 & 2929.95 & 0.001 \\
\hline Attitude & $\begin{array}{l}\text { Intervention Group } \\
\text { Control Group }\end{array}$ & 1 & 80 & 336.58 & 0.001 & 1 & 80 & 3620.76 & 0.001 \\
\hline Practice & $\begin{array}{l}\text { Intervention Group } \\
\text { Control Group }\end{array}$ & 1 & 80 & 129.23 & 0.001 & 1 & 80 & 3116.72 & 0.001 \\
\hline
\end{tabular}

higher practice of the participants in the intervention group with $76.7 \%$, while the level of practice in the control group remained unchanged (76.9\%) moderate practice. These findings reveals that the level of practice changes with the educational intervention (Table 2).

Table 3 shows Repeated Measures ANOVA for within-subject and between-subject effects in both groups. Within subject-effects revealed significant difference for knowledge $[F(1.80)=876.25$, $\mathrm{p}=0.001]$, attitude $[\mathrm{F}(1.80)=336.58, \mathrm{p}=0.001)$, and practice $[F(1.80)=129.23, p=0.001)$. These results reject the null hypothesis as there was a significant improvement in the level of knowledge, attitude, and practice over-time withinsubject effect in the intervention group.
Repeated measures ANOVA also revealed significant difference between subject-effect in the level of knowledge, attitude, and practice over time after participants attended the educational intervention. The results indicate post-test improvement in knowledge $[\mathrm{F}(1.80)=2929.95, \mathrm{P}=0.001]$, attitude $[\mathrm{F}(1.80)=3620.76, \mathrm{P}=0.001]$, and practice $[\mathrm{F}$ $(1.80)=3116.72, P=0.001]$. These results showed educational intervention does improve the level of knowledge, attitude, and practice.

\section{DISCUSSION}

This study relates to the findings of other studies where the level of performance has brought a significant improvement after an educational intervention to healthcare workers ${ }^{11}$. Educational train- 
ing helps nurses and physicians to provide proper treatment and diagnosis when their knowledge, attitude, and practice have increased ${ }^{12}$. Nurses' technique were found to be enhanced after an intervention training using a simulated dressing model ${ }^{13}$. Another study mentioned ${ }^{14}$ that $69 \%$ of the medical students felt confident in their level of knowledge of management in surgical and medical wounds after the course, and $76 \%$ felt there is a need to have an elective wound care education as a part of the medical school curriculum. However, not every medical school offered adequate duration for wound care education ${ }^{15}$. Adequate wound care education to medical student implied a positive impact when employed where students with exposure to various wound management showed an improvement in the level of knowledge. A survey was conducted to two different groups of medical students. Evaluation of the level of knowledge on chronic wound care management in groups of medical students in their pre- and post-clinical years has showed significant improvement ${ }^{16}$.

Having a good level of knowledge had an effect on good practice and a positive attitude on wound care management. Delayed wound healing or non-healing wound could be prevented if all healthcare professionals have good fundamentals of knowledge, attitude, and practice ${ }^{17}$.

A similar study conducted on educational intervention to improve rural and remote practitioners' knowledge of diabetic foot ulcers revealed not only the level of knowledge has significantly improved, but the participants' ability to identify high-risk categories was reportedly improved after the training ${ }^{18}$. Those who attended wound care management course practised complete aseptic technique which suggested that the need for an educational course is profound ${ }^{\text {. }}$.

In the recent systematic reviews digital education were found to be effective, but the blended mode was even more superior and exclusive as compared to the digital platform when it comes to selecting the mode of educational intervention. Blended mode education program has higher knowledge retention, higher satisfaction, and proved to be superior to the rest ${ }^{19}$. This study showed health professionals had more confidence in treating patients and improved the quality of life for the patient, after the educational intervention.

\section{CONCLUSION}

Wound care management posits a wide range of elements where substantial knowledge, attitude, and practice of healthcare professionals are essential. Educational intervention on wound care management is moving ahead, and it has been proven effective to enhance the related knowledge, attitude, and practice. The levels of knowledge, attitude, and practice have tremendously improved after the educational intervention which suggests that the educational intervention module was effective and could be further expanded to the other health facilities.

\section{ACKNOWLEDGEMENTS}

We would like to thank the Director General of Health Malaysia for the permission to publish this article. The authors would also like to express their gratitude to the Sabah State Health Department, particularly Penampang Area Health Office and Putatan District Health Office. We would also like to thank again the Ministry of Health of Malaysia for the approval to use the Wound Care Manual as a tool and guidelines in this study.

\section{REFERENCES}

1. Broughton G, Janis JE, Attinger CE. A brief history of wound care. Plast Reconstr Surg. 2006;117(7 SUPPL.):611. [CrossRef]

2. Chaby G, Senet P, Vaneau M, et al. Dressings for acute and chronic wounds: A systematic review. Arch Dermatol. 2007;143:1297-1304. [CrossRef]

3. AWC L, MR Z, Helmy H, Ramdhan I. Economic Impact of Managing Acute Diabetic Foot Infection in a Tertiary Hospital in Malaysia. Malaysian Orthop J. 2014;8:46-9. [CrossRef]

4. Chun D, Kim S, Kim J, et al. Epidemiology and Burden 
of Diabetic Foot Ulcer and Peripheral Arterial Disease in Korea. J Clin Med. 2019;8:748. [CrossRef]

5. Greenwell K, Sivyer K, Vedhara K, et al. Intervention planning for the REDUCE maintenance intervention: A digital intervention to reduce reulceration risk among patients with a history of diabetic foot ulcers. BMJ Open. 2018;8:1-12. [CrossRef]

6. Harries RL, Bosanquet DC, Harding KG. Wound bed preparation: TIME for an update. Int Wound J. 2016;13:814. [CrossRef]

7. Hrynchak P, Batty $H$. The educational theory basis of team-based learning. Med Teach. 2012;34:796-801. [CrossRef]

8. Ministry of Health Malaysia. Management of Diabetic Foot (Second Edition). 2018.

9. Alla B. An Observational Study on Wound Dressing Performance among Nurses in Adult Units Quality Indicator Specialist. Nurs Res Clin Pract Manag. 2018;7:1-6. [CrossRef]

10. Ministry of Health Malaysia. Clinical Practice Guidelines on Diabetic Foot Care. Vol 18.; 2018. [CrossRef]

11. O'Brien KE, Chandramohan V, Nelson DA, Fischer JR, Stevens G, Poremba JA. Effect of a physician-directed educational campaign on performance of proper diabetic foot exams in an outpatient setting. J Gen Intern Med. 2003; 18:258-65. [CrossRef]

12. Lagerin A, Nilsson G, Törnkvist L. An educational intervention for district nurses: use of electronic records in leg ulcer management. J Wound Care. 2007;16:29-32. [CrossRef]

13. Kent DJ. Effects of a just-in-time educational intervention placed on wound dressing packages: A multicenter randomized controlled trial. J Wound, Ostomy Cont Nurs. 2010;37:609-14. [CrossRef]

14. Yim E, Sinha V, Si D, Rs K, Cj S. Wound healing in US medical school curricula . 2014;22:12198. [CrossRef]

15. Patel NP, Granick MS, Kanakaris NK, Giannoudis P V, Werdin F, Rennekampff H-O. Comparison of wound education in medical schools in the United States, United kingdom, and Germany. Eplasty. 2008;8:e8.

16. Akhiyat S, Mcnish S, Couch KS, Shanmugam VK. Medical Student Competency in Wound Care Guidelines. Georg Washingt Univ. 2016:13888.

17. Dilie A, Mengistu D. Assessment of Nurses' Knowledge, Attitude, and Perceived Barriers to Expressed Pressure Ulcer Prevention Practice in Addis Ababa Government Hospitals, Addis Ababa, Ethiopia, 2015. Adv Nurs. 2015;2015:1-11. [CrossRef]

18. Schoen DE, Gausia K, Glance DG, Thompson SC. Improving rural and remote practitioners' knowledge of the diabetic foot: Findings from an educational intervention. J Foot Ankle Res. 2016;9:1-11. [CrossRef]

19. Martinengo L, Ying NYJ, Markandran KD, Olsson M, Kyaw BM, Car LT. Digital health professions education on chronic wound management: a systematic review. Int J Nurs Stud. 2019;104:103512. [CrossRef] 